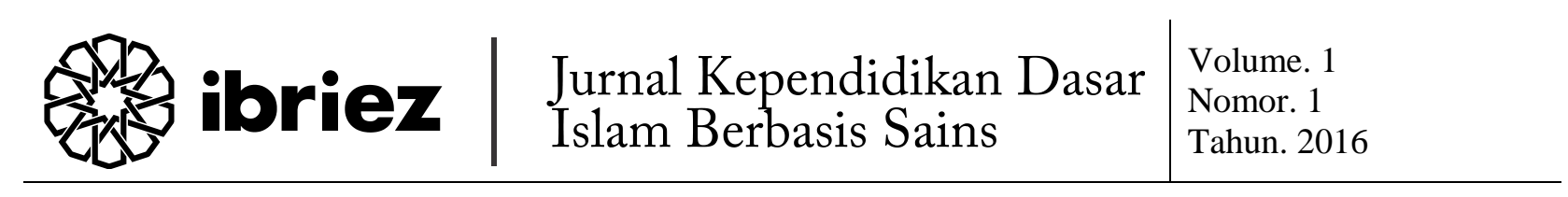

\title{
Kontribusi Quantum Learning terhadap Perkembangan Kecerdasan Interpersonal Siswa SD
}

\author{
Weni Tria Anugrah Putri \\ Tarbiyah STAIN Ponorogo \\ Wtriaanugrahputri@gmail.com
}

\begin{abstract}
Abstrak
Dalam upaya peningkatan hasil pembelajaran, hal ini semakin mendorong upaya guru untuk merancang sebuah pembelajaran yang mampu mengakomodasi segala jenis hasil pembelajaran. Hasil pembelajaran yang tidak hanya berkaitan dengan penguasaan materi, namun juga berkaitan dengan karakter siswa. Karakter-karakter yang bermakna untuk siswa dalam menghadapi kehidupan sosial. Kehidupan sosial siswa tidak hanya dalam lingkungan keluarga dan sekolah. Ketika siswa melakukan kesalahan masih terdapat pihak-pihak yang mampu menegur dengan cara yang baik. Tidak bisa dipungkiri lagi jika kehidupan siswa juga dalam lingkungan masyarakat, yang di dalamnya membutuhkan kecerdasan interpersonal yang lebih baik dalam menghadapinya. Kajian ini bertujuan untuk memberikan rekomendasi pembelajaran yang mampu mewadahi tidak hanya hasil pembelajaran kognitif namun juga afektif. Hasil belajar afektif berupa kemampuan menerima dan memperhatikan suatu objek, menanggapi, menghargai, mengatur atau mengorganisasikan, serta menginternalisasi nilai-nilai menjadi pola hidup. Kajian ini ditujukan pada kemampuan siswa dalam bekerjasama, bergotong royong, dan menjalin hubungan yang baik dalam berbagai macam lingkungan. Dengan bercermin dari pembelajaran yang seringnya berpusat pada guru yang menjadikan siswa cenderung lebih pasif, maka diharapkan selanjutnya pembelajaran mampu menjadikan siswa sebagai pusat pembelajaran agar memberikan hasil pembelajaran yang tidak hanya dalam ranah kognitif.
\end{abstract}

Kata Kunci: kecerdasan interpersonal; pembelajaran kuantum; afektif

\section{A. PENDAHULUAN}

Dalam sebuah pembelajaran, hasil merupakan sesuatu hal yang sangat penting. Hal ini sejalan dengan pernyataan yang terdapat dalam UU no. 20 tentang sistem pendidikan nasional yang berbunyi pendidikan merupakan usaha sadar dan terencana untuk membuat suasana belajar dan proses pembelajaran menjadi kondusif sehingga mapu mengembangkan potensi spiritual, pengendalian diri, kepribadian, kecerdasan, akhlak mulia, serta keterampilan yang diperlukan untuk diri sendiri, masyarakat, bangsa dan negara. ${ }^{1}$ Dalam pernyataan tersebut dinyatakan

1 Republik Indonesia, "Undang-Undang Republik Indonesia Nomor 20 Tahun 2003 Tentang Sistem Pendidikan Nasional," 2003, 27. 
bahwa hasil pembelajaran tidak hanya berkaitan dengan kemampuan siswa menyerap materi pembelajaran, namun juga berkaitan dengan hal lain.

Sejalan dengan pendapat tersebut, Rahyubi menyampaikan bahwa sebuah pembelajaran ditujukan agar siswa memperoleh ilmu dan pengetahuan, penguasaan kemahiran dan tabiat, serta pembenatukan sikap dan kepercayaan. ${ }^{2}$ Pembelajaran tidak hanya berkaitan dengan penguasaan terhadap pengetahuan. Karakter merupakan salah satu hal yang perlu didalami dalam sebuah pembelajaran. Hasil dari sebuah pembelajaran tidak hanya untuk laporan tertulis dari guru kepada seorang siswa, namun untuk jangka panjang. Hasil jangka panjang dalam sebuah pembelajaran salah satunya adalah karakter seorang siswa setelah mengikutinya.

Salah satu bentuk karakter yang merupakan hasil pembelajaran adalah kemampuan siswa dalam bekerja sama dan bersosialisasi dengan teman sejawatnya. Tidak dipungkiri bahwa kemampuan siswa dalam bidang ini sangat penting. Dengan berpedoman bahwa di masa depan, siswa akan semakin banyak tantangan mengenai dunia sosial. Semakin baik hubungan sosial seseorang, maka semakin besar pula peluang kesusksesan siswa.

Demikian pula pendapat Daryanto yang menyatakan bahwa pembelajaran ditujukan untuk penguasaan pengetahuan, kemampuan, keterampilan, dan sikap yang dimiliki siswa. ${ }^{3}$ Berdasarkan pendapat para ahli tersebut, karakter merupakan salah

\footnotetext{
2 Heri Rahyubi, Teori-Teori Belajar Dan Aplikasi Pembelajaran Motorik: Deskripsi Dan Tinjauan Kritis, ed. Nurdin (Bandung: Referens, 2014), 6.

${ }^{3}$ Daryanto, Evaluasi Pendidikan (Jakarta: Rineka Cipta, 2005), 58.
}

satu hal penting yang harus ada dalam output sebuah pembelajaran.

Situasi yang berkembang dalam kehidupan sehari-hari seperti yang disampaikan oleh Nastiti menyatakan bahwa dalam observasinya, siswa kurang mampu bekerja sama ketika melakukan pembelajaran. ${ }^{4}$ Hal ini berdasarkan siswa yang terlihat masih individual meskipun sudah dibentuk sebuah kerja kelompok. Pada umumnya siswa masih ingin memilih teman yang dijadikannya kelompok, terutama teman yang memiliki kedekatan. Hal inilah yang akhirnya menyebabkan siswa enggan untuk berkumpul dengan teman sekelompok yang telah dipilihkan guru secara heterogen. Pengelompokan yang dilakukan dengan tidak memperhatikan kedekatan antar siswa juga akan menyebabkan siswa akan saling mengejek dan akhirnya kerjasama dalam kelompok tidak terlaksana dengan maksimal. Hal lain yang dilakukan siswa yaitu siswa melakukan tindakan protes karena tidak menyukai teman satu kelompok yang dipilihkan ole guru.

Begitu pula dengan observasi yang dilakukan oleh Anggraeni yang menyimpulkan bahwa sebuah pembelajaran teacher center mengakibatkan siswa bekerja secara sendiri-sendiri untuk mencapai tujuan pembelajaran. ${ }^{5}$ Hal ini terlihat dari guru yang membiarkan siswa-siswanya mengerjakan tugas-tugas Matematika dikerjakan secara individual. Peneliti

\footnotetext{
${ }^{4}$ Filumena Ajeng Nastiti, "Peningkatan Kerjasama Dan Prestasi Belajar IPS Dengan Pembelajaran Kooperatif STAD Pada Siswa Kelas III SD Kanisius Kintelas I Yogyakarta" (Universitas Sanata Dharma, 2014), 5.

${ }^{5}$ Viana Teti Anggraeni, Sutama, and Samino, "Dampak Komunikasi Siswa Terhadap Hasil Belajar Matematika Sekolah Dasar," Varia Pendidikan 26, no. 1 (June 2014): 70 .
} 
menganggap bahwa dengan pekerjaan yang dilakukan secara individual akan menyebabkan siswa menganggap sulit sebuah soal yang dianggapnya sulit. Bagi siswa tersebut tidak ada siswa lain yang mampu diajaknya untuk membahas soal, dengan alasan belum memiliki kedekatan dan alasan lain. Peneliti tersebut berasumsi bahwa meskipun materi Matematika yang pada umumnya berkaitan dengan simbol, tabel dan diagram, namun pemilihan metode pembelajaran tetap harus menumbuhkan kemampuan komunikasi. Hal ini bertujuan agar ketika siswa merasa kesulitan terhadap sebuah soal, maka siswa mampu mengkomunikasikannya dengan baik untuk sekedar sharing dengan siswa lain, entah berada di lingkungan sekolah ataupun di lingkungan luar sekolah. Berdasarkan dua hasil observasi tersebut, maka secara umum karakter kerja sama dan kesan individual dalam sebuah pembelajaran masih sering terjadi.

Kerjasama dengan individu lain bertujuan untuk kelangsungan hidup manusia, sehingga terjadi keluarga, organisasi, ataupun sekolah. ${ }^{6}$ Berdasarkan pendapat tersebut, dapat disimpulkan bahwa dalam kesehariannya, seorang siswa memerlukan sikap ini untuk masa depannya, serta untuk peluan-peluang yang mungkin muncul dari segala hubungan sosialnya.

Pembelajaran yang mampu mengintegrasikan kerjasama, memberikan kesempatan kepada siswa agar mampu berkomunikasi dengan lebih baik antar teman. Sebuah pepatah lama mengatakan

\footnotetext{
6 Anita Lie, Cooperative LearningMempraktekkan Cooperative Learning Di Ruang-Ruang Kelas (Jakarta: Gramedia Widiasarana Indonesia, 2005), 7.
}

bahwa ketika seseorang ingin menjadi yang tercepat, maka hendaklah bepergian sendiri. Jika seseorang menginginkan hasil paling jauh, maka hendaklah bekerja sama. Supaya pembelajaran memperoleh hasil yang paling dalam, maka komunikasi yang baik antar siswa sangat diperlukan.

Kemampuan siswa dalam bekerjasama dan bersosialisasi salah satunya ditandai dengan ketidakambiguannya dan kejelasannya dalam menyampaikan pendapat. Semakin sering seorang siswa berosialisasi, maka semakin baik dalam hubungan pergaulannya.

Di salam sebuah kerjasama, maka dapat diindentifikasi bahwa terdapat individu yang mampu membuat hubungan yang tepat dengan individu lain, mampu memahami sudut pandang dan sikap individu lain. Selain itu, terdapat individu yang mampu mengurangi sifat egois, mampu berteman dan berkenalan dengan pribadi lain dengan mudah. Satu hal lagi yaitu, individu yang mampu bekerjasama adalah individu yang dengan mudah menolong sesama, karena dengan saling menolonglah sebuah hubungan akan semakin dekat dan kerjasama akan semakin mudah dilakukan.

Seorang siswa yang mampu menjalin hubungan dengan baik dengan sesama, maka dengan mudah pula untuk melakukan kerjasama dan berkomunikasi. Kemampuan inilah yang pada umumnya disebut sebagai kecerdasan interpersonal. Hal tersebut merupakan bekal yang mampu digunakan siswa setelah pendidikan formalnya. Dengan kata lain akan menentukan tingkat keberhasilan seseorang setelah pendidikan formal. Dengan kecerdasan interpersonal, 
seorang individu mampu berkomunikasi dan memahami keberadaan individu lain.

Dengan merujuk serangkain pendapat di atas, maka sebuah pembelajaran diharapkan mampu mengakomodasi kebutuhan siswa selain dalam penguasaan materi pembelajaran. Quantum learning merupakan salah satu model yang mampu digunakan untuk mewadahi pembelajaran kerjasama, gotong royong, bersosialisasi dengan baik. Dengan hanya menyesuaikan tujuan pembelajaran, maka pembelajaran kuantum mampu memberikan hasil maksimal terhadap penguasaan materi dan karakter lainnya.

\section{B. KAJIAN TEORI}

Secara umum, pembelajaran merupakan sebuah aktivitas yang dilakukan siswa untuk mendapatkan ilmu dan pengetahuan tertentu. Terdapat banyak ahli pendidikan yang mendefinisikan istilah tersebut sesuai dengan pemahaman masingmasing. Begitu pula dengan Schunk yang mendefinisikan pembelajaran perilaku dalam jangka waktu yang lama dengan indikator memiliki kapasitas tertentu berdasarkan pengalaman tertentu ${ }^{7}$. Dengan demikian, maka tidak hanya ada sebuah perubahan yang terjadi setelah aktivitas pembelajaran dan berakhir dengan singkat, namun juga memberikan efek jangka panjang. Lebih rinci lagi, Rahyubi mengungkapkan bahwa pembelajaran merupakan aktivitas pemberian bantuan dari pendidik kepada siswa agar memperoleh ilmu dan pengetahuan, penguasaan kemahiran dan

\footnotetext{
${ }^{7}$ Daleh H. Schunk, Learning Theories-an Educational Perspective, ed. Erika Setyowati, trans. Eva Hamdiah and Rahmat Fajar (Yogyakarta: Pustaka Pelajar, 2012), 5 .
}

karakter, serta pembentukan sikap dan kepercayaan ${ }^{8}$.

Berdasarkan pendapat kedua ahli tersebut, di dalam pembelajaran terdapat tiga hal yang dapat digarisbawahi. Pertama adalah perilaku pemerolehan ilmu dan pengetahuan melalui pengalaman yang terlihat dari pengkondisian pembelajaran. Kedua adalah terjadinya perubahan dalam diri siswa selain memiliki kemampuan kognitif (pengetahuan), afektif (sikap) dan juga psikomotorik (kemahiran dan keterampilan). Perubahan kognitif berkenaan dengan penguasaan siswa terhadap empat jenis pengetahuan. Adapun empat jenis pengetahuan yaitu pengetahuan faktual, konseptual, prosedural dan metakognitif ${ }^{9}$ Perubahan afektif juga berkenaan tentang kepedulian, kepercayaan diri, keingintahuan, keberanian, persahabatan, fleksibilitas, kerendahan hati, humoris, inisiasi, integritas, kemampuan menentuan tujuan, kesabaran, ketekunan, pemecahan masalah, disiplin diri, kerjasama ${ }^{10}$. Ketiga adalah hasil pembelajaran bertahan dalam jangka waktu relatif lama pada memori siswa.

Dengan adanya pendefinisian yang berbeda-beda dari para ahli, semakin mengerucutkan makna pembelajaran. Meskipun demikian, terdapat tujuh prinsip pembelajaran yang harus ada di dalam sebuah pembelajaran yang baik, yaitu perhatian dan motivasi, keaktifan, keterlibatan langsung, pengulangan, tantangan, feedback dan

\footnotetext{
8 Rahyubi, Teori-Teori Belajar Dan Aplikasi Pembelajaran Motorik: Deskripsi Dan Tinjauan Kritis, 6.

${ }^{9}$ Lorin W. Anderson and David R. Krathwohl, eds., Pembelajaran, Pengajaran, dan Asesmen: Revisi Taksonomi Pendidikan Bloom, trans. Agung Prihantoro (Yogyakarta: Pustaka Pelajar, 2010), 61-62.

${ }^{10}$ Sharron L. McElmeel, Character Education: A Book Guide for Teachers, Librarians, and Parents (United States of America: Teacher Ideas Press, 2002), xxiiixxiv.
} 
penguatan, serta perbedaan individu ${ }^{11}$. Ketujuh prinsip tersebut mampu digunakan sebagai dasar untuk memperbaiki hasil belajar siswa ${ }^{12}$.

Perhatian dan motivasi. Berdasarkan hasil penelitian Putri, maka dapat disimpulkan bahwa motivasi merupakan salah satu hal yang berperan penting dalam meningkatkan hasil belajar $^{13}$. Motivasi membuat seorang siswa merasa senang mendalami suatu materi pembelajaran. Sejalan dengan hasil penelitian tersebut, Sobur mengungkapkan bahwa dalam mencapai tujuan, seseorang memerlukan motivasi yang digambarkan dalam lingkaran motivasi (motivational cycle), yang secara garis besar tercermin atas kebutuhan, tingkah laku, dan tujuan ${ }^{14}$.

Dengan demikian, jika seorang siswa merasa membutuhkan sebuah ilmu pengetahuan, maka siswa tersebut akan tertarik dalam mengikuti pembelajaran. Sebagai contoh, seorang siswa yang ingin mengetahui bagaimana cara membuat sebuah keterampilan tangan yang layak jual, akan menjadikannya tertarik perhatiannya untuk mengikuti mata pelajaran keterampilan. Jika seorang siswa telah merasa tertarik terhadap pembelajaran, maka tingkah laku yang sesuai bidang yang menariknya tersebut akan senantiasa menjadi indikasi yang mudah dilihat. Jika seorang siswa telah melaksanakan sesuatu sesuai materi pembelajaran yang dianggapnya menarik, maka secara tidak langsung, aktivitasnya mengarah pada tujuan yang

\footnotetext{
11 Dimyati and Mudjiono, Belajar Dan Pembelajaran (Jakarta: Rineka Cipta, 1999), 42-50.

12 Ibid., 42.

${ }^{13}$ Weni Tria Anugrah, review of Pengaruh Motivasi Belajar dan Pemahaman Konseptual terhadap Hasil Belajar Matematika pada Materi Keliling dan Luas Bangun Dasar Sederhana Siswa Sekolah Dasar, by Siti Maghfiroh Amin and M. V. Roesminingsih, Jurnal Review Pendidikan Dasar 1 (1) (2015): 75-80.

${ }^{14}$ Alex Sobur, Psikologi Umum (Bandung: Pustaka Setia, 2003), 270-73.
}

diinginkannya. Begitu pula tujuan yang diinginkan sesuai dengan kebutuhannya.

Hal ini diperkuat dengan pernyataan Gage dan Berliner yang menyatakan bahwa tanpa adanya perhatian, maka pembelajaran tidak bisa terlaksana ${ }^{15}$. Hal ini diperkuat oleh hasil penelitian di salah satu sekolah dasar yang menyatakan bahwa ketika guru sedang mengajar, terdapat banyak siswa yang mengantuk dan tidak mendengarkan ${ }^{16}$. Berdasarkan kedua hal di atas, maka keterlaksanaan pembelajaran tidak hanya terlihat ketika guru memasuki kelas dan memulai pembelajaran tanpa melihat kondisi siswa. Jikalau guru memasuki kelas dan melaksanakan pembelajaran yang dirasa kurang menarik, maka hal itu belum dikatakan sebagai pembelajaran. Menelaah pendapat sebelumnya, telah disampaikan bahwa terdapat perubahan yang terjadi setelah siswa melaksanakan pembelajaran, namun apabila belum terjadi perubahan maka dapat disimpulkan bahwa belum terjadi pelaksanaan pembelajaran.

Keaktifan. Adanya jiwa yang aktif dalam pembelajaran, yang ditunjukkan melalui tingkah laku, tidak sekedar menyimpannya saja disebut sebagai indikator siswa telah melaksanakan pembelajaran ${ }^{17}$. Kemampuan mengonstruk sebuah pengetahuan, mampu membuat perencanaan serta menggunakan pengetahuan yang telah diperolehnya merupakan indikasi keaktifan dan keterlibatan seorang siswa dalam mengikuti pembelajaran. Keterlibatan siswa inilah yang menjadikan

15 Gage N. L. and C. Berliner David, Educational Psychology (Chicago: Rand Mc Nally College Publishing Company, 1984), 335.

${ }^{16}$ Weni Tria Anugrah, "Penggunaan Media Film Kartun untuk Meningkatkan Keterampilan Menyimak Cerita Siswa Kelas V SDN Takeran Magetan" (Skripsi, Universitas Negeri Surabaya, 2013), 3.

${ }^{17}$ N. L. and David, Educational Psychology, 267. 
senantiasa mampu mendalami materi pembelajaran.

Keterlibatan. Jika seorang siswa dirasa aktif dalam sebuah pembelajaran, maka dapat disimpulkan bahwa individu tersebut memiliki keterlibatan dengan pembelajaran yang sedang berlangsung. Hal ini sesuai dengan pendapat Dewey yang menyatakan bahwa belajar sebaiknya dialami melalui perbuatan langsung ${ }^{18}$. Dengan terlibat secara langsung, akan tercipta pengalaman bagi siswa. Pengalaman tersebut akan menjadikan pembelajaran lebih bermakna dan mudah diingat. Pengalaman menjadikan seorang siswa mampu memanipulasi objek pembelajaran secara langsung. Berdasarkan hal tersebut, maka pembelajaran akan jauh dari kesan verbalisme.

Pengulangan. Pengulangan yang dimaksudkan yaitu berupa latihan yang diberikan kepada siswa setelah mendapatkan sebuah materi pembelajaran. Latihan dianggap mampu membuat pembelajaran sempurna ${ }^{19}$. Sebuah materi pembelajaran harus diberikan pengulangan supaya lebih mampu tersimpan dalam memori individu dalam jangka waktu relatif lama (memori jangka panjang). Sebagai contoh, jika seorang guru sedang memukul meja dengan keras agar suasana kelas menjadi lebih tenang dan mengulanginya hingga beberapa kali dalam seminggu, maka akan membuat para siswa secara otomatis diam saat guru memukul meja.

Tantangan. Di dalam Teori Medan dijelaskan bahwa ketika melaskanakan pembelajaran, siswa berada di dalam suatu

\footnotetext{
18 Dimyati and Mudjiono, Belajar Dan Pembelajaran, 45-46.

19 Mohamad Nur, Prima Retno Wikandari, and Bambang Sugiarto, trans., Teori Pembelajaran Kognitif (Surabaya: Pusat Sains dan Matematika Sekolah UNESA, 2008), 34.
}

kondisi psikologis ${ }^{20}$. Ketika berhadapan dengan materi pembelajaran yang semakin lama semakin kompleks, seorang siswa akan mengalami suatu kendala. Kendalanya yaitu meneruskan mempelajari materi tersebut ataukah berhenti dengan indikasi acuh saat pembelajaran. Dengan adanya materi pembelajaran yang menarik akan menjadikan siswa meneruskan mempelajari materi tersebut. Kondisi tertantang inilah yang dianggap para ahli sebagai sebuah kondisi psikologis yang dialami siswa dalam merespon sebuah materi pembelajaran baru. Berdasarkan pendapat tersebut, maka seyogyanya materi pembelajaran diusahakan menjadi sebuah materi yang menarik siswa untuk tertantang mengikutinya.

Feedback dan Penguatan. Penguatan dalam hal ini bisa diberikan kepada siswa yang telah berhasil ataupun sebaliknya dalam menguasai materi pembelajaran. Penguatan yang diberikan ketika seorang siswa berhasil menguasai materi pembelajaran yaitu berupa pujian, hadiah, sertifikat penghargaan. Penguatan yang diberikan ketika seorang siswa belum berhasil dalam menguasai materi pembelajaran yaitu berupa membebaskan siswa dari tugas yang dinilai berat dan tidak diharapkan. Sebagai contoh, jika seorang siswa mampu menguasi materi pembelajaran, maka kewajibannya untuk mengikuti ulangan harian akan dihilangkan atau dibebaskan dari ulangan harian.

Perbedaan Individual. Di dalam sebuah kelas, heterogenitas siswa memang sangat terasa. Adapun perbedaan yang sering terlihat yaitu adanya perempuan dan laki-laki, perbedaan kemampuan dalam menyerap ilmu, perbedaan fisik dan berbagai perbedaan lainnya. Hal inilah yang menjadi kewajiban

\footnotetext{
${ }^{20}$ Dimyati and Mudjiono, Belajar Dan Pembelajaran, 47.
} 
seorang guru untuk memperhatikan perbedaan siswa. Jika guru tidak memaklumi dan memahami adanya perbedaan ini, maka pembelajaran pun akan terhambat. Sebagai contoh, seorang siswa yang sedang menderita rabun jauh, tidak boleh diberikan tempat duduk di belakang, bukan sebaliknya.

\section{Quantum Learning}

Deporter dan Hernacky menyatakan bahwa pembelajaran kuantum merupakan gabungan sugestologi, accelerated learning, neurolinguistic programming (NLP) dengan teori keyakinan dan langkah-langkah tertentu ${ }^{21}$. Dengan adanya sugesti yang positif, maka seseorang akan mengikuti sebuah aktivitas dengan senang hati. Sebaliknya, jika seseorang memiliki sugesti negatif, maka hanya akan setengah hati dalam mengikuti. Dengan demikian, seorang guru harus memiliki kemampuan untuk membangun sugesti yang positif dalam diri siswa saat pembelajaran. Kondisi kelas yang nyaman, hubungan pertemanan yang baik, karakter guru yang ramah dan cerdas, dan segala yang mendukung proses pembelajaran akan menjadikan siswa memiliki sugesti (kesan) yang baik dalam mengikuti pembelajaran.

Program pemercepatan (accelerated learning) ditujukan untuk siswa yang ingin belajar lebih cepat dari standarnya. Aspek ini mendukung adanya pembelajaran kuantum, tentunya dengan kondisi yang menyenangkan namun mampu menyerap materi lebih banyak. Dengan demikian, menyenangkan menjadi salah satu hal yang perlu diperhatikan oleh guru dalam mempersiapkan sebuah pembelajaran.

21 Bobbi DePorter and Mike Hernacki, Quantum Learning: Membiasakan Belajar Nyaman dan Menyenangkan, ed. Sari Meutia, trans. Alwiyah Abdurrahman (Bandung: Kaifa, 2015), 16.
Program neurolingusitik secara umum diartikan sebagai program yang di dalamnya terdapat pemilihan ungkapan-ungkapanyang positif oleh guru yang bertujuan agar siswa mampu memberikan respon yang positif pula. Hal ini merupakan sebentuk rangsangan untuk otak siswa agar mampu dikondisikan untuk belajar. Guru yang menginstruksikan siswa dengan bahasa yang baik, akan menjadikan siswa memberikan respon yang baik pula, begitu pula sebaliknya.

Berdasarkan penjabaran tersebut, terlihat bahwa dasar dari quantum learning adalah pemahaman guru terhadap siswa. Untuk itu, guru yang baik bukanlah guru yang hanya memiliki penguasaan terhadap materi yang hendak diajarkan tetapi juga seseorang yang mampu mendalami siswanya. Pendalaman inilah yang nantinya akan mempermudah guru untuk menyampaikan materi pembelajaran. Sebagai contoh, seorang guru yang hendak mengajar materi perkalian, maka hendaknya tidak langsung mengajarkan materi tersebut, namun berusaha menunjukkan hubungan dengan materi yang sebelumnya. Dengan cara ini, memori yang ada di dalam siswa untuk materi yang sebelumnya tidak terhapus sia-sia.

Contoh pemahaman lainnya yaitu perbedaan intelegensi siswa. Guru harus menyadari bahwa tidak semua siswa dalam satu kelas memiliki tingkatan IQ yang sama. Hal ini bermakna bahwa, bukan berarti dengan tingkatan intelegensi yang berbeda, guru dengan mudah mampu memberikan pelabelan terhadap siswanya. Berbekal hal tersebut, guru harus bertindak agar pembelajaran tetap berhasil meskipun memiliki siswa yang berbeda-beda.

Sumarna dan Kosasih merangkum prinsip-prinsip Quantum Learning dalam beberapa poin. Adapun prinsip-prinsip tersebut 
adalah (1) membawa pesan, (2) memiliki tujuan, (3) pengalaman sebelum pelabelan, (4) pengakuan terhadap semua usaha, (5) perayaan keberhasilan. Pembelajaran ini hendaknya mampu menjadikan hal-hal di sekelilingnya memiliki arti dan mampu menyampaikan pesan. Lingkungan yang sesuai dengan materi pembelajaran, mampu mendukung pemrosesan materi di dalam memori siswa ke dalam jangka panjang. Kurikulum yang menarik, guru yang menyenangkan, suasana kelas yang kondusif, suara guru yang lantang, kesemuanya diistilahkan mampu membawa pesan dalam sebuah pembelajaran karena mampu mendukung keberhasilan pembelajaran.

Keterlibatan semua aspek dalam sebuah pembelajaran diharapkan memiliki tujuan. Hal ini dikarenakan di setiap langkah pembelajaran, jika terdapat aspek yang sebenarnya tidak memiliki kaitan dengan pembelajaran akan menjadikan kendala bagi pemrosesan informasi pada diri siswa. Sebuah pembelajaran perkalian di sekolah dasar tidak memerlukan media berupa gambar-gambar rumus fisika. Hal ini dikarenakan bahwa semua hal yang terlibat dalam sebuah pembelajaran haruslah memiliki tujuan yang mendukung tujuan pembelajaran. Semua hal yang terlibat dalam pembelajaran diharapkan mampu memberikan perubahan dalam diri siswa setelah pembelajaran.

Pada umumnya, pembelajaran diibaratkan memberikan semua makanan dan meminta siswa untuk langsung memakannya. Di pembelajaran kuantum, siswa diibaratkan harus mampu membuat makanan sendiri. Dengan kata lain, pelabelan terhadap sebuah peristiwa, kejadian, atau konsep haruslah siswa yang melakukan, sebelum guru memberitahukan label yang sebenarnya. Seorang siswa yang sedang mempelajari sinonim dan antonim, pada mulanya guru harus membiarkan siswa untuk memahaminya terlebih dahulu dengan istilah persamaan kata dan lawan kata serta memberikan contoh sebanyak mungkin. Pada akhirnya guru memberikan istilah yang tepat untuk persamaan kata dan lawan kata.

Pengakuan setiap usaha oleh guru dan teman sebaya kepada diri siswa teramat penting. Hal ini bertujuan agar siswa memiliki keberanian untuk mendalami materi pembelajaran. Ketika guru memberikan pertanyaan kepada siswa dan mengacuhkan siswa yang sedang menjawab pertanyaannya, maka akan menjadikan siswa merasa enggan untuk mendalami materi tersebut. Perhatian guru dan aura wajah yang menyenangkan serta kemauan menjawab setiap pertanyaan siswa dengan baik juga merupakan sebentuk pengakuan oleh seorang guru kepadanya siswanya.

Dalam setiap pembelajaran, guru diharapkan mampu memberikan penguatan yang positif kepada siswa berupa pujian, hadiah dan penghargaan kepada siswa. Hal ini bertujuan agar siswa memiliki kemauan untuk melanjutkan pendalaman materi pembelajaran. Pendalaman materi ini memiliki indikator berupa kemajuan dan peningkatan hasil belajar. Selanjutnya, penguatan yang positif juga bertujuan mendekatkan guru dengan psikologis siswa, sehingga dapat digunakan guru untuk mengatasi problematika yang ditemui siswa di pembelajaran selanjutnya.

Adapun karakteristik yang dimiliki oleh Quantum Learning ${ }^{22}$ antara lain: (1) berpangkal pada paikologi kognitif; (2) lebih manusiawi; (3) lebih bersifat konstruktif, (4) mensinergikan faktor potensi individu dengan lingkungan fisik dan psikis dalam konteks pembelajaran, (5) memusatkan perhatian pada interaksi yang bermutu dan bermakna, (6) menekankan pada akselerasi pembelajaran dengan taraf keberhasilan yang tinggi, (7) menekankan kealamiahan dan kewajaran proses pembelajaran, (8) menekankan proses yang bermakna, (9) memiliki model yang memadukan konteks dan isi pembelajaran, (10)

\footnotetext{
22 Nandang Kosasih and Dede Sumarna, Pembelajaran Kuantum Dan Optimalisasi Kecerdasan, ed. Ajat Rukajat and (pertama) (Bandung: Alfabeta, 2013), 79.
} 
memusatkan perhatian pada pembentukan keterampilan akademis, keterampilan hidup, dan prestasi fisikal, (11) menempatkan nilai dan keyakinan, (12) mengutamakan keberagaman dan kebebasan, (13) mengintegrasikan totalitas fisik dan pikiran. Sejumlah karakter tersebut menggambarkan bahwa metode ini sangat mengutamakan kebermaknaan sebuah pembelajaran yang didukung oleh faktor-faktor lain.

Di dalam pembelajaran kuantum, guru tidak hanya diwajibkan mengaplikasikan kurikulum ke dalam strategi, metode, teknik dan langkah-langkah pembelajarannya, namun juga memahami kebutuhan siswa ${ }^{23}$. Penguasaan guru terhadap materi yang diajarkan merupakan hal yang penting. Pengetahuan guru tentang strategi, metode, teknik dan menyusun langkah-langkah pembelajaran juga merupakan hal yang penting. Walaupun demikian, yang sering terlupakan ketika guru mengajar adalah tidak menyesuaikannya pembelajaran dengan kebutuhan siswa. Sebagai contoh, seorang guru yang telah menguasi materi menyimak dalam Bahasa Indonesia dan menguasi seluruh jenis strategi, teknik, dan metode pembelajaran akan mampu mengajar di kelas dari awal hingga selesainya waktu pembelajaran, namun belum tentu guru telah memahami apa yang dibutuhkan siswa di awal perancangan pembelajaran.

Sejalan dengan pemahaman guru terhadap kebutuhan siswa, desain lingkungan dalam pembelajaran kuantum juga merupakan faktor pendukung keberhasilan metode ini. Lingkungan menjadi hal penting dalam proses belajar mengajar, karena secara langsung lingkungan akan terlibat dalam setiap proses tersebut. Lingkungan yang dimaksud yaitu berupa lingkungan di sekeliling proses pembelajaran, media pembelajaran, bangku yang digunakan siswa, keharuman dalam kelas, unsur tumbuhan dan hewan dalam kelas. Lingkungan sekeliling yang nyaman, disertai dengan kelengkapan sarana dan prasarana akan menjadikan siswa bertahan lama

\footnotetext{
${ }^{23}$ Ibid., 80.
}

dalam proses pembelajaran. Media pembelajaran yang menarik dan sesuai dengan materi pembelajaran akan menjadikan siswa merasa lebih tertarik dan menjauhkan kebosanan dalam pembelajaran. Aroma kelas yang harum atau setidaknya tidak tercium aroma yang kurang sedap mampu menjadikan siswa bertahan lama dalam ruangan kelas. Suasana sekeliling pembelajaran yang rindang bahkan guru mampu mengintegrasikan lingkungan ke dalam pembelajaran mampu mensiasati kebosanan yang dialami siswa ketika proses pembelajaran. Pengaturan bangku yang pada umumnya menjadikan guru sebagai center dan berada di depan kelas bisa dimodifikasi sesuai dengan kebutuhan pembelajaran dan karakteristik siswa di kelas tersebut. Adapun beberapa pengaturan tempat duduk yaitu meja konferensi, formasi huruf $\mathrm{U}$, formasi corak tim, lingkaran, workstation, kelompok untuk kelompok, chevron, breakout grouping, auditorium, bahkan kelas tradisional pun masih mampu digunakan asal sesuai dengan kebutuhan ${ }^{24}$.

\section{Kecerdasan Interpersonal}

Gardner mengklasifikasikan terdapat beberapa jenis kecerdasan, salah satunya yaitu kecerdasan interpersonal ${ }^{25}$. Kecerdasan merupakan kemampuan siswa menangkap sesuatu yang baru di dalam lingkungannya dan kemampuannya menjadikan pembelajaran terhadap sesuatu yang telah lalu ${ }^{26}$. Terdapat dua hal yang dapat digarisbawahi, yaitu tentang masa lalu dan keadaan saat ini. Dengan adanya berbagai macam kondisi yang nyata, seorang siswa yang memiliki kecerdasan akan mampu memberikan solusi dalam mengatasi suatu masalah. Kemampuannya melihat masalah tidak hanya

24 Ibid., 136-44.

25 Ibid., 176.

26 Thomas Amstrong, Setiap Anak Cerdas: Panduan Membantu Anak Belajar Dengan Memanfaatkan Multiple Intelligence-Nya (Jakarta: Gramedia Pustaka, 2002), 2. 
melihat masalah secara pribadi, namun belajar dari masalah orang lain. Kemampuan siswa tersebut bersumber pada kemampuan berpikir yang semakin berkembang secara maksimal. Dengan demikian dapat disimpulkan bahwa kecerdasan merupakan sebuah perkembangan berpikir pada diri seseorang sehingga menjadikannya mampu melihat sebuah masalah dan mampu memberikan solusi serta mampu menjadikan sebuah problematika pribadi dan orang lain sebagai pembelajaran di masa depan.

Kecerdasan interpersonal merupakan kecerdasan seorang siswa dalam hubungannya dengan siswa lain. Kecerdasan tersebut termasuk kemampuan berempati, memimpin, dan mengorganisir siswa lain ${ }^{27}$. Kemampuan siswa berempati terhadap orang lain akan menjadikannya memahami posisi orang lain, sehingga ketika berkomunikasi pun akan memperhatikan kondisi orang lain. Dengan kemampuannya ini, akan menjadikannya murah untuk mengorganisir siswa lain ketika pembelajaran berlangsung.

Terdapat instruksi tertentu untuk siswa yang memiliki kecerdasan ini. Guru harus menyadari bahwa dalam suatu kelas terdapat siswa-siswa yang heterogen. Untuk menghadapi siswa yang memiliki kecerdasan ini, maka guru hendaknya menginstruksikan siswa dalam kerja kelompok, menjadikannya tutor sebaya atau menggunakan metode diskusi dalam sebuah pembelajaran ${ }^{28}$. Untuk mengetahui siswa yang memiliki kecerdasan interpersonal, terdapat beberapa karakteristik yang bisa diamati. Adapun karakteristik siswa tersebut antara lain: 1) mampu belajar dan membangun interaksi dalam sebuah komunitas, 2) berpikir bahwa semakin

\footnotetext{
27 Kosasih and Sumarna, Pembelajaran Kuantum Dan Optimalisasi Kecerdasan, 178.

28 Ibid., 183.
}

berinteraksi dengan orang lain akan membuat semakin bahagia, 3) produktif dan berkembang dengan pembelajaran kolaboratif dan kooperatif, 4) menyukai chatting di dalam media sosial, 5) berpartisipasi dalam organisasi social, 6) menyukai acara talkshow di televisi, 7) lebih senang bermain dalam tim, 8) cepat bosan ketika bekerja sendiri, 9) melibatkan diri dalam kegiatan ektrakurikuler, 10) peduli terhadap isu sosial ${ }^{29}$. Secara umum, siswa yang memiliki kecerdasan interpersonal cenderung mampu menyesuikan diri dengan komunitas di dekatnya.

Sejalan dengan rincian karakteristik tersebut, Anderson dan Safaria menyimpulkan bahwa terdapat tiga dimensi kecerdasan dimensi utama yaitu social sensitivity, social insight, dan social communication ${ }^{30}$. Sensitifitas sosial merupakan kemampuan siswa dalam merasakan perubuahan yang terdapat di dalam lingkungan sosialnya, biasanya berwujud empati dan prososial. Pemahaman sosial merupakan kemampuan siswa dalam memahami dan mencari solusi dalam permasalahan yang ada hubungannya dengan interaksi sosial, yang biasanya berwujud berupa etika sosial.

\section{Karakteristik Perkembangan Siswa Sekolah Dasar}

Pada usia sekolah dasar, siswa berada pada tahap perkembangan operasional konkrit, yaitu pada usia 7-11 tahun $^{31}$. Pada tahap perkembangan ini, siswa memiliki kecenderungan membutuhkan instruksi dari guru yang nyata dan mengutamakan ketepatan. Instruksi nyata yang diberikan guru,

\footnotetext{
${ }^{29}$ Muhammad Yaumi, "Pembelajaran Berbasis Multiple Intelligences," Jakarta: Dian Rakyat, 2012, 147.

30 T. Safaria, "Interpersonal Intelligence: Metode Pengembangan Kecerdasan Interpersonal Anak," Yogyakarta: Amara Books, 2005, 24.

31 Sudarwan Danim, Perkembangan Peserta Didik (Bandung: Alfabeta, 2013), 64.
} 
menjadikan siswa memiliki kesempatan untuk mempelajari sebuah materi dengan nyata pula. Keberadaan media pembelajaran sangat dianjurkan dalam sebuah pembelajaran untuk siswa pada tahap perkembangan ini. Dengan keberadaannya, siswa mampu memanipulasi dan menghubungkannya dengan materi pembelajaran yang sedang berlangsung.

Selanjutnya, otak dan system syaraf juga berkembang ke arah maksimal. Perkembangan otak siswa sekolah dasar ditandai dengan pertumbuhan struktur yang lebih spesifik. Hal inilah yang menjadikan siswa semakin mampu merencanakan, menalar, melakukan penilaian sosial, etika dan pengambilan keputusan dengan lebih baik ${ }^{32}$. Dengan demikian siswa semakin mampu mengerjakan tugas-tugas yang semakin kompleks dan sulit secara lebih baik. Indikator lain berupa semakin sistematisnya pola pikir siswa, sehingga karakter umum berupa egosentris magis semakin terkikis.

Adapun karakteristik siswa sekolah dasar secara umum dirangkum dalam Ahmadi dan Munawar, yaitu minat terhadap kehidupan praktis sehari-hari yang konkret, realistis, keinginan belajar sangat tinggi, telah memiliki minat terhadap hal-hal khusus, masih membutuhkan keberadaa orang dewasa untuk membantu mengerjakan tugas-tugas sekolah, mengganggap nilai rapor sebagai patokan yang paling valid, dan gemar membentuk kelompok bermain $^{33}$. Seringkali terlihat bahwa orang tua siswa terlibat dalam setiap tugas siswa, bahkan bukan rahasia umum lagi bahwa terkadang yang mengerjakan beberapa tugas adalah orang tua siswa. Bertolak belakang dengan hal tersebut, siswa sudah memiliki minat terhadap

\footnotetext{
32 Ibid., 61.

33 Abu Ahmadi and Munawar Sholeh, Psikologi Perkembangan (Jakarta: Rineka Cipta, 2005), 25.
}

hal-hal spesifik, misalnya memiliki minat terhadap pekerjaan di masa mendatang.

\section{PEMBAHASAN}

Berdasarkan penjelasan sebelumnya, dapat diketahui bahwa kecerdasan interpersonal merupakan salah satu jenis kecerdasan majemuk yang penting dalam sebuah pembelajaran. Widjaya merangkum tujuan adanya kecerdasan interpersonal antara dengan adanya kecerdasan ini, seorang siswa mampu mengenal diri sendiri; mengenal dunia luar; menciptakan dan memelihara hubungan; mengubah sikap dan perilaku; bermain dan mencari hiburan; membantu orang lain. ${ }^{34}$ Dengan demikian, kecerdasan interpersonal tidak hanya dibutuhkan dalam pembelajaran namun juga berperan penting dalam kehidupa sehari-hari siswa. Salah satu wahana yang memfasilitasi pengembangan kecerdasan interpersonal adalah pembelajaran di sekolah, salah satunya adalah di sekolah dasar.

Dengan adanya kecerdasan interpersonal, seorang siswa memiliki kesempatan untuk mengenal diri sendiri lebih dalam. Hal ini berdasarkan bahwa semakin sering seorang siswa melakukan interaksi antarpribadi, maka akan semakin besar kesempatannya untuk membicarakan tentang dirinya sendiri. Dengan pengetahuan tersebut, akan menjadikannya memiliki pandangan baru terhadap diri sendiri yang akhirnya berdampak pada sikap yang ditunjukkan kepada orang lain untuk kondisi selanjutnya.

Pengenalan dunia luar seringkali terjadi karena adanya interaksi antar

34 A. W. Widjaja, Ilmu Komunikasi (Jakarta: Bina Aksara, 2000), 122. 
pribadi. Semakin banyak pribadi yang dikenal oleh seorang siswa maka semakin banyak pula informasi tentang dunia luar didapatkan. Pengenalan dunia luar ini dimaksudkan tidak hanya mengenal tetapi juga menjaga hubungan baik dan tidak membuat perpecahan. Dengan menjaga hubungan antar pribadi akan menjadikan seorang siswa diakui keberadaannya oleh siswa lain. Hal inilah yang membuat seorang siswa merasa lebih percaya diri dalam melaksanakan pembelajaran.

Berdasarkan uraian tersebut, kecerdasan interpersonal tercermin dalam menjaga hubungan yang baik antarpribadi. Seorang siswa yang memiliki kecerdasan interpersonal akan mampu menjaga hubungan baik antarsesama.

Seseorang yang memiliki kecerdasan interpersonal selain dengan mudah mendapatkan informasi mengenai diri sendiri dan informasi mengenai dunia luar, juga akan mempermudah dirinya untuk mempengaruhi sikap siswa lain. Semakin dekat hubungan siswa dengan siswa lain, akan menjadikannya mudah untuk mempersuasi sikap siswa lain. Seorang siswa yang memiliki kecerdasan ini akan dengan mudahnya mempengaruhi temannya untuk tidak mengerjakan pekerjaan rumah. Begitu juga dengan pemikiran seorang siswa akan dengan mudahnya dipengaruhi oleh orang terdekatnya.

Bermain dan mencari hiburan merupakan dua hal yang biasanya terjadi bersamaan. Aktivitas ini membuat seorang siswa bisa melepas ketegangan dalam mengikuti pembelajaran yang konservatif. Terkadang banyak yang menganggap dua aktivitas ini merupakan hal yang tidak penting, namun hal ini bisa mengurangi kejenuhan dalam menjalankan aktivitas.

Tidak hanya berkaitan dengan perbaikan hasil belajar yang baik, kecerdasan interpersonal akan menjadikan seorang siswa semakin jelas terhadap citacitanya. Pekerjaan-pekerjaan yang membutuhkan kecerdasan ini antara lain guru, dokter, pegawai bank, dan terapis. Dengan memiliki kecerdasan ini, seorang siswa akan terbiasa menghadapi situasi sosial. Secara tidak langsung, hal ini mampu mendidik siswa untuk lebih dekat terhadap cita-citanya.

Berdasarkan tujuan kecerdasan interpersonal bagi siswa yang telah diuraikan, maka hal ini bisa ditumbuhkan melalui quantum learning. Hal ini tercermin dari langkah-langkah pembelajaran kuantum, yaitu siswa harus mampu mengidentifikasi manfaat yang ada pada sebuah pembelajaran, yang disebut dengan indetifikasi ambak (apa manfaatnya bagiku). Selanjutnya yaitu tentang penataan lingkungan belajar; memupuk sikap juara pada siswa; guru membebaskan gaya belajar siswa; membiasakan siswa untuk mencatat materi yang dipelajari; membiasakan membaca; menjadikan anak lebih kreatif; serta melatih kekuatan memori siswa ${ }^{35}$.

Pada tahapan menjadikan anak lebih kreatif, siswa dibebaskan mencoba sesuatu melalui manipulasi dan bermain. Dengan adanya permainan ini, siswa akan mengenal lingkungannya. Tidak hanya lingkungan abiotik namun juga lingkungan pertemanan. Dengan kondisi tersebut, siswa mampu berbagi dalam beberapa hal dengan teman-

35 DePorter and Hernacki, Quantum Learning: Membiasakan Belajar Nyaman dan Menyenangkan. 
temannya. Secara tidak langsung, siswa mampu belajar berbagi dan menjalin hubungan baik dengan pribadi yang lain.

Jika pada mulanya siswa tidak mampu bersosialisasi dengan siswa yang lain, maka kebebasan siswa untuk bermain secara tidak langsung akan mengkondisikannya untuk berbagi. Begitu pula bagi siswa yang cenderung mudah bersosialisasi dengan siswanya, akan semakin meningkatkan kecerdasan interpersonalnya.

Sebagai contoh, penelitian yang dilakukan oleh Noor Izzati tentang pembelajaran kuantum dengan materi bunyi dengan langkah-langkah: 1) guru menumbuhkan minat siswa sehingga siswa merasa benar-benar membutuhkan materi tersebut untuk dipelajari, hal ini sesuai dengan langkah ambak (mengindentifikasi apa manfaatnya bagiku); 2) guru mengkondisikan siswa mengalami bagaimana menciptakan bunyi; 3) guru mengkondisikan siswa melaporkan hasil pembelajaran bunyi; 4) guru memberikan kesempatan kepada siswa untuk mensdemonstrasikan kemampuannya tentang materi bunyi di depan temantemannya; 5) guru mengistruksikan siswa untuk mengulangi konsep yang dikuasainya; 6) guru bersama siswa merayakan atau memberikan apresiasi terhadap pencapaian siswa. ${ }^{36}$ Pada tahapan keempat, siswa mendemonstrasikan konsep

\footnotetext{
36 Isna Noor Izzati, "Peningkatan Hasil Belajar IPA Melalui Model Pembelajaran Kuantum Pada Siswa Kelas IV SD Negeri Banyuputih 04 Kecamatan Kalinyamatan Kabupaten Jepara Tahun Pelajaran 2008/ 2009” (Universitas Sebelas Maret, 2009), 54-55, http://eprints.uns.ac.id/6613/1/100410709200909441.pd f.
}

yang dikuasai, menjadikan siswa merasa percaya diri untuk tampil di depan kelas.

Percaya diri tampil di depan umum merupakan salah satu indikator adanya kecerdasan interpersonal. Hal ini sesuai dengan pendapat Safaria yang menyatakan bahwa salah satu indikasi kecerdasan interpersonal adalah berbicara dengan efektif dalam sebuah forum. ${ }^{37}$

Prinsip pembelajaran kuantum salah satunya semua hal yang ditemui siswa dalam pembelajaran adalah bermakna. Lingkungan di sekitar, semua harus memiliki manfaat terhadap pembelajaran. Begitu pula dengan hubungan antar pribadi yang terjadi di dalam kelas juga harus memberikan manfaat terhadap pembelajaran yang sedang berlangsung. Dengan demikian pembelajaran kuantum tidak hanya penguasaan materi oleh siswa sebagai hasilnya. Hal lain yang dicapai salah satunya yaitu hubungan pribadi antar siswa yang semakin membaik.

Dalam pengaplikasiannya, pembelajaran kuantum tidak hanya berpusat pada penilaian individu, sehingga dalam pembelajaran tidak terdapat pengelompokan. Sebaliknya, pembelajaran juga boleh dilakukan dengan pengelompokan siswa. Hal inilah yang juga semakin menjadikan pembelajaran kuantum mendukung adanya pengembangan kecerdasan interpersonal.

Dengan pembelajaran yang berkelompok, dan setelah itu diadakan permainan, maka pembelajaran kuantum semakin mampu menjadi wahana untuk mengembangkan kecerdasan interpersonal siswa sekolah dasar. Hal utama yang dituju yaitu siswa mampu berbagi dengan siswa

\footnotetext{
${ }^{37}$ Safaria, "Interpersonal Intelligence," 25.
} 
lain dan selalu menjaga hubungan pertemanan dengan baik.

Dalam kehidupan sehari-hari sering dijumpai anak-anak yang masih memiliki sifat egosentris yang dominan, yang merupakan ciri khas usia anak. Ada kalanya egosentrisme memiliki peran dalam kehidupan seorang individu, namun seringkali hal ini perlu dikurangi. Hal ini disebabkan oleh sifat khas manusia sebagai makhluk sosial dalam arti tidak mampu menjalani kehidupan tanpa orang lain.

Egosentrisme secara umum diartikan sebagai segala hal yang menjadikan diri sendiri sebagai pusat dalam segala hal. Dalam fase perkembangannya, sifat egosentris diperlukan agar anak memiliki kepercayaan diri dalam masa pertumbuhannya. Hal inilah yang terkadang menyebabkan sifat egosentris masih saja muncul ketika usia sekolah dasar. Usia-usia di mana siswa yang seharusnya sedikit demi sedikit mengurangi sifat ini.

Berdasarkan penjelasan singkat tentang egosentris, maka pembelajaran yang baik adalah pembelajaran yang mampu mengurangi sifat tersebut. Jika siswa yang diajari ini masih dalam tahap awal, kecenderungan akan merasa asing akan besar, namun hasil yang diperoleh akan membekali siswa untuk masa depannya.

\section{KESIMPULAN}

Upaya peningkatan hasil pembelajaran yang dilakukan oleh guru ada berbagai cara. Hasil belajar tidak hanya berkaitan dengan penguasaan materi atau yang biasa disebut hasil belajar dalam ranah kognitif. Hasil belajar juga berkaitan dengan afektif dan psikomotor siswa.
Quantum learning merupakan salah satu solusi yang mampu digunakan guru dalam mampu mengarahkan siswa agar siswa mampu bersosialisasi, bekerjasama, dan gotong royong dalam sebuah kelas. Pada akhirnya criteria inilah yang disebut sebagai kecerdasan interpersonal.

Dengan quantum learning, seorang guru mampu memaksimalkan semua hal yang terdapat di sekeliling siswa untuk membantu keberhasilan sebuah pembelajaran. Lingkungan, musik, hubungan pertemanan, konsep yang diketahui oleh siswa sebelumnya mampu dimanfaatkan untuk sebuah pembelajaran yang menarik. Dengan membuat siswa menjadi berkelompok-kelompok dan menyajikannya dalam sebuah permainan, maka tidak hanya penguasaan materi secara kognitif namun mampu lebih dari hal tersebut.

\section{E. DAFTAR PUSTAKA}

Ahmadi, Abu, and Munawar Sholeh. Psikologi Perkembangan. Jakarta: Rineka Cipta, 2005.

Amstrong, Thomas. Setiap Anak Cerdas: Panduan Membantu Anak Belajar Dengan Memanfaatkan Multiple Intelligence-Nya. Jakarta: Gramedia Pustaka, 2002.

Anderson, Lorin W., and David R. Krathwohl, eds. Pembelajaran, Pengajaran, dan Asesmen: Revisi Taksonomi Pendidikan Bloom. Translated by Agung Prihantoro. Yogyakarta: Pustaka Pelajar, 2010.

Anggraeni, Viana Teti, Sutama, and Samino. "Dampak Komunikasi Siswa Terhadap Hasil Belajar Matematika Sekolah Dasar." Varia Pendidikan 26, no. 1 (June 2014).

Danim, Sudarwan. Perkembangan Peserta Didik. Bandung: Alfabeta, 2013.

Daryanto. Evaluasi Pendidikan. Jakarta: Rineka Cipta, 2005. 
DePorter, Bobbi, and Mike Hernacki. Quantum Learning: Membiasakan Belajar Nyaman dan Menyenangkan. Edited by Sari Meutia. Translated by Alwiyah Abdurrahman. Bandung: Kaifa, 2015.

Dimyati, and Mudjiono. Belajar Dan Pembelajaran. Jakarta: Rineka Cipta, 1999.

Kosasih, Nandang, and Dede Sumarna. Pembelajaran Kuantum Dan Optimalisasi Kecerdasan. Edited by Ajat Rukajat and (pertama). Bandung: Alfabeta, 2013.

Lie, Anita. Cooperative LearningMempraktekkan Cooperative Learning Di Ruang-Ruang Kelas. Jakarta: Gramedia Widiasarana Indonesia, 2005.

McElmeel, Sharron L. Character Education: A Book Guide for Teachers, Librarians, and Parents. United States of America: Teacher Ideas Press, 2002.

N. L., Gage, and C. Berliner David. Educational Psychology. Chicago: Rand Mc Nally College Publishing Company, 1984.

Nastiti, Filumena Ajeng. "Peningkatan Kerjasama Dan Prestasi Belajar IPS Dengan Pembelajaran Kooperatif STAD Pada Siswa Kelas III SD Kanisius Kintelas I Yogyakarta." Universitas Sanata Dharma, 2014.

Noor Izzati, Isna. "Peningkatan Hasil Belajar IPA Melalui Model Pembelajaran Kuantum Pada Siswa Kelas IV SD Negeri Banyuputih $04 \quad$ Kecamatan Kalinyamatan Kabupaten Jepara Tahun Pelajaran 2008/ 2009." Universitas Sebelas Maret, 2009. http://eprints.uns.ac.id/6613/1/10041 0709200909441.pdf.

Nur, Mohamad, Prima Retno Wikandari, and Bambang Sugiarto, trans. Teori Pembelajaran Kognitif. Surabaya: Pusat Sains dan Matematika Sekolah UNESA, 2008.

Rahyubi, Heri. Teori-Teori Belajar Dan Aplikasi Pembelajaran Motorik: Deskripsi Dan Tinjauan Kritis. Edited by Nurdin. Bandung: Referens, 2014.

Republik Indonesia. "Undang-Undang Republik Indonesia Nomor 20 Tahun 2003 Tentang Sistem Pendidikan Nasional," 2003.
Safaria, T. "Interpersonal Intelligence: Metode Pengembangan Kecerdasan Interpersonal Anak." Yogyakarta: Amara Books, 2005.

Schunk, Daleh H. Learning Theories-an Educational Perspective. Edited by Erika Setyowati. Translated by Eva Hamdiah and Rahmat Fajar. Yogyakarta: Pustaka Pelajar, 2012.

Sobur, Alex. Psikologi Umum. Bandung: Pustaka Setia, 2003.

Weni Tria Anugrah. Review of Pengaruh Motivasi Belajar dan Pemahaman Konseptual terhadap Hasil Belajar Matematika pada Materi Keliling dan Luas Bangun Dasar Sederhana Siswa Sekolah Dasar, by Siti Maghfiroh Amin and M. V. Roesminingsih. Jurnal Review Pendidikan Dasar 1 (1) (2015): 75-80.

. "Penggunaan Media Film Kartun untuk Meningkatkan Keterampilan Menyimak Cerita Siswa Kelas V SDN Takeran Magetan." Skripsi, Universitas Negeri Surabaya, 2013.

Widjaja, A. W. Ilmu Komunikasi. Jakarta: Bina Aksara, 2000.

Yaumi, Muhammad. "Pembelajaran Berbasis Multiple Intelligences." Jakarta: Dian Rakyat, 2012. 
140 | ibriez $\left|\begin{array}{l}\text { Jural Kependidikan Dasar } \\ \text { Islam Berpasis Sains }\end{array}\right|$ Vol 1 No 1 Tahun 2016 